\title{
MANAGERIAL DECISIONS ON THE NATURE AND SCALE OF CORPORATE ACTIVITY DIVERSIFICATION IN THE CONSTRUCTION SECTOR
}

\author{
ROMUALDAS GINEVIČIUS
}

\begin{abstract}
A B S T R A C T
Corporate activity diversification is a promising but at the same time risky condition of a company's adaptation to the business environment. Effectiveness of diversification processes in enterprises may be achieved by research in the following areas: development of methods of internal and external business environment analysis as a basis for diversification decisions; understanding the dependence of the scope and nature of corporate activity diversification on the market situation; providing sciencebased advice for the management of diversified companies, especially large ones; improvement in the methods of diversification measuring so that a complex analysis of the diversification process would become implementable. Based on the study of the Lithuanian construction sector, this paper seeks to provide new insights into the following aspects of corporate activity diversification: preconditions and conditions for deciding on corporate activity diversification; the problem of the scale and nature of diversification; organisational management conditions for the success of diversification projects. Furthermore, an in-depth discussion of the problematic of measuring the achieved level of diversification is offered.
\end{abstract}

KEY WORDS

corporate activity diversification, construction sector, success factors, diversification measurement

10.2478/emj-2020-0015 pages: $7-17$
Corresponding author:

Romualdas Ginevičius

Bialystok University of Technology, Poland ORCID 0000-0003-2067-4398 e-mail: r.ginevicius@pb.edu.pl

\section{INTRODUCTION}

Today, the success of economic agents is determined not by their ability to launch products or provide services, but by their capacity to sell them in the market. Thus, the strategic focus of businesses is shifted from the area of production to marketing, i.e. the area of market relations. Companies need to be aware of both new opportunities and emerging threats so as to take advantage of the former and prevent the latter. Development of the ability to adapt

Citation: Ginevičius, R. (2020). Managerial decisions on the nature and scale of corporate activity diversification in the construction sector. Engineering Management in Production and Services, 12(3), 7-17. doi: 10.2478/emj-2020-0015 
is the most effective way to implement any business strategy. In a constantly changing environment, companies survive only if the complexity and dynamics of their decisions are adequate to the changes in the external environment (Ansoft, 1965), which was particularly clearly revealed by the global financial crisis of 2009-2010. The construction, wholesale and retail sectors were hit hardest by the shrinking markets - they went bankrupt. This was because companies in the above-mentioned sectors did not have any independent sources of revenue.

Risk reduction and long-term financial stability are the main objectives of corporate activity diversification (Amik et al., 1988; Schüle, 1992; Montgomery, 1994; Ginevičius, 1998a, 2008b; Kieser \& Kubicek, 1992). A diversified company can achieve the first objective by offsetting losses in declining markets with the gain from growing ones. The cycles of achieving the second objective are depicted in Figure 1.

The literature on a product life cycle distinguishes four stages of this cycle: creation and introduction, growth, maturity and decline (Gort \& Klepper, 1982; Maksimovic \& Gordon, 1995; Dickinson, 2005; Zhipeng, 2006). To maintain stable revenue, losses caused by a fall in sales of one product (stage 4) are offset by an increase in sales of another one that is in the third stage of its life cycle (Fig. 1).

Company's ability to adapt to changing external requirements can only be achieved through corporate growth (Ansoff, 1965) which, however, must not be passive (i.e. directed only to save the positions already occupied) because market growth is the main precondition for both global and national economic development. For this reason, companies need to expand their activities to the extent that would allow them to maintain growth rates no lower than those of the general market. Only in this case, they can expect to raise or at least to maintain their market shares.

Diversification is one of the four basic corporate growth strategies (Ansoff, 1965). It is based on three essential principles: first, the introduction of the products that differ from those already produced to such an extent that they can be sold in new markets; second, entry into new markets that differ from current ones to such an extent that it makes sense to develop the volumes of production; third, the development of the long-term production expansion schemes without damaging the part which reflects the current corporate production nomenclature (Arbeitskreis, 1973).

Because corporate diversification is a process of great complexity and even controversy, the opinions on its strategical efficiency in terms of corporate adaptation to the external environment are still conflicting (Amik et al., 1989; Ansoff, 1957, 1965). Several decades of scholarship on this topic present a nuanced view on when and how diversification might be beneficial to an enterprise (Miller, 2006; Pennings et al., 1994; Teece et al., 1993; Wan \& Hoskisson, 2003). Even today, although the first steps of corporate activity diversification were made in the USA as early as 1850 and gathered pace immediately after World War II, many questions remain unanswered (Lehmann, 1993). The main relevant issues are as follows:

- preconditions and conditions for deciding on corporate activity diversification;

- the problem of the scale and nature of diversification;

- organisational management conditions for the success of diversification projects;

- measuring the achieved level of diversification.

This article addresses all the above-mentioned issues.

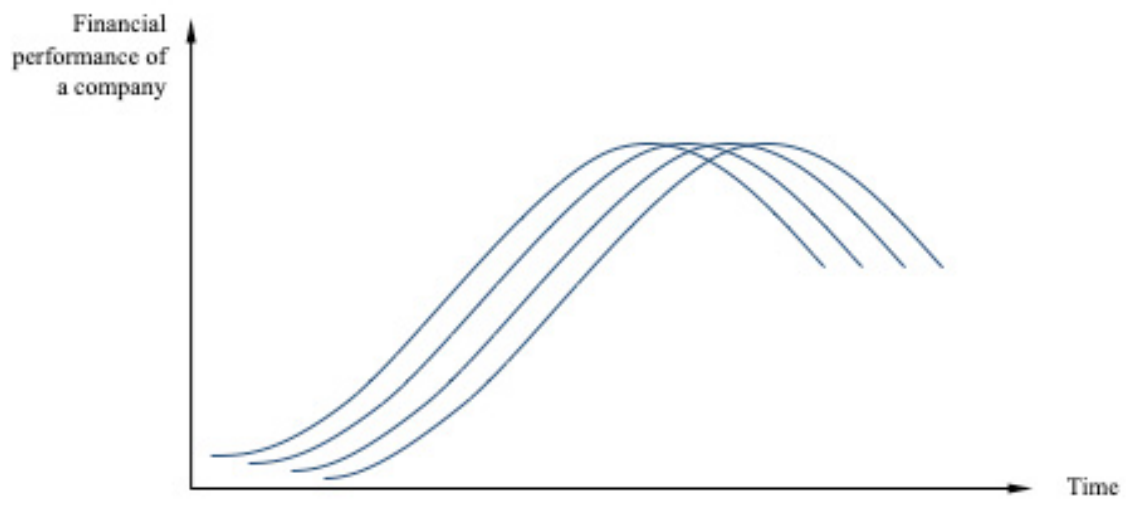

Fig. 1. Company's product life cycles 


\section{PRECONDITIONS AND CONDITIONS FOR DECISION- MAKING ON CORPORATE ACTIVITY DIVERSIFICATION}

Ansoff's four corporate growth strategies can be divided into two groups (Pierscionek, 1966):

- expansion strategies (market penetration, development and product improvement);

- diversification.

The choice of one of the two options must be based on the analysis of internal and external business conditions because namely this analysis determines corporate growth prospects. The above-mentioned strategies reveal long-term sale forecasts based on the trends in national economic policies, international indicators, business specifics, competition, cost fluctuations and so forth. If it turns out that expansion strategies do not provide any opportunities to develop the current business and thus increase the volume of products or services, or if there is a risk of a decline in a company's market share, then the company should further grow through diversification.

As already mentioned before, Ansoff's concept of a strategy choice is based on the analysis of internal and external business environment (Ansoff, 1957) (Fig. 2).

On the other hand, it is widely acknowledged that diversification, as a corporate growth strategy, plays an increasingly important role in business management, and a growing number of international corporations rely on in their activities. For instance, in recent years, it has been implemented by more than 94 per cent of the world's top 500 corporations (Li et al., 2013). The importance of diversification has grown significantly in the context of business internationalisation, which is particularly noticeable in developing economies (Chen et al., 2014).

Many previous studies address the impact of diversification on different corporate activity aspects: reinvestment strategies (Mackey \& Barney, 2013), capital costs and structure (Hann et al., 2013), the effects of banking activity diversification on stock markets (Sawada, 2013), company's value (Kuppuswamy et al., 2014; Hyland, 2003; Jara-Bertin et al., 2015; Nazarova, 2015), the profitability of business operations (Zahavi \& Lavie, 2013; Becerra \& Santaló, 2006; Santarelli \& Tran, 2016; Knapková et al., 2019; Bilan et al. 2019), and the need of technologies for the implementation of the diversification process ( $\mathrm{Li}$ et al., 2013; Wang et al., 2014). Many studies focus on the impact of corporate ownership on the processes of diversification (Chung, 2013; Hernández-Trasobares \& Galve-Górriz, 2016; Schmid et al., 2015; Sanchez-Bueno \& Usero, 2014). Geographical diversification of business companies (Chonghui et al., 2013; Thoumrungroje \& Tansuhaj, 2005; Gaur \& Delios, 2015; Qian et al., 2013; Yahaya et al., 2009; Mauer et al., 2015), diversification risks (Busse et al., 2014; Yücel \& Önal, 2015), the processes of diversification in business networks (Kim et al., 2014; Chen \& Jaw, 2014) are areas of continuous interest among researchers.

Internal environment assessment is based on the SWOT analysis, i.e. identification of a company's strengths, weaknesses, opportunities and threats, while the main purpose of external environment assessment is to identify what opportunities a company has to capture new markets. In the context of increasing complexity and dynamics of national and global economic systems, the analysis of enterprise's environment requires application of

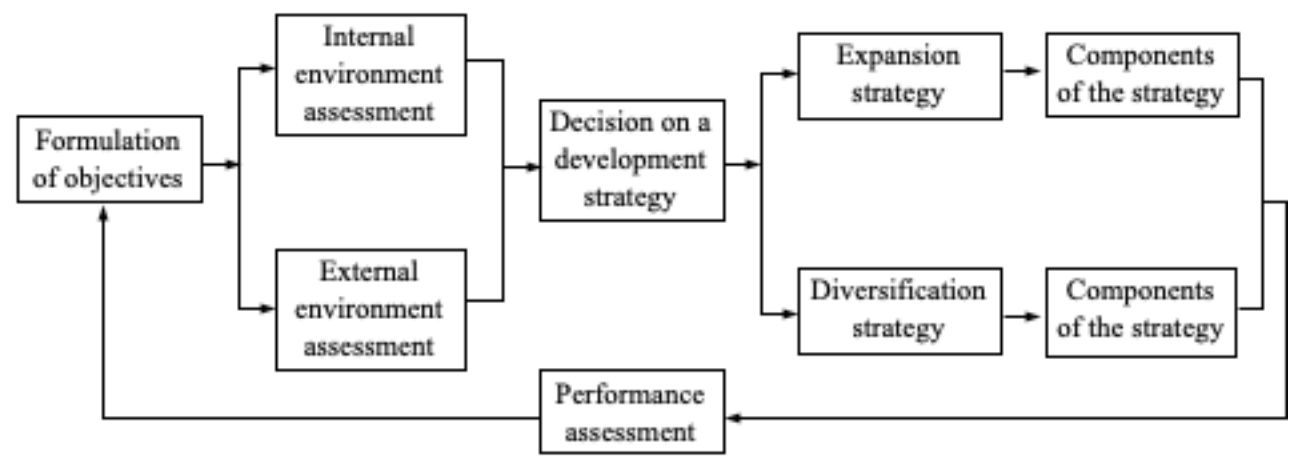

Fig. 2. Scheme of the corporate strategy formation process

Source: author's elaboration on the basis of (Ansoff, 1957). 
sophisticated methods grounded in the foresight logic (Nazarko et al., 2007a; Nazarko et al., 2007b; Ejdys et al., 2019). Such analyses are relevant to all economic sectors (Nazarko et al., 2015), including construction. The analysis should also comprise assessment of the potential of a new business, the synergies expected from capturing new markets, etc. (Ginevičius, 1998).

\section{PROBLEM OF THE SCALE AND NATURE OF DIVERSIFICATION}

The problem of the scale and nature of diversification covers several aspects: first, identification of the scale or, in other words, the number of simultaneous activities; second, the technological relation among the conducted activities.

The basis for tactical actions while implementing a particular diversification strategy is the so-called corporate core skill (Wrigley, 1970). This concept refers to the general ability of a company to accurately and effectively accumulate the knowledge of markets and technologies for profit, growth, and thus external adaptation. Basically, the core skill reflects a company's professionalism and its strategic potential. It determines how many and what types of activities a company can conduct considering the situation in the market.

The scale of diversification, or the number of simultaneous activities, reflects the quantitative nature of the diversification process, while the technological relation among the conducted activities is linked to the technological similarity of these activities. In this sense, a distinction is made between related and unrelated diversification. Related diversification refers to the expansion of the new products manufactured or sold within the corporate core skill. Unrelated diversification, on the contrary, refers to the inclusion of such products that require the skills outside the corporate core skill. The latter type virtually reflects the qualitative side of diversification.

All aspects of the scale and nature of diversification are closely linked together (Fig. 3).
Figure 3 proposes that both quantitative and qualitative parameters of the process of corporate activity diversification depend on the market situation. A market can be growing, shrinking or steady. When the market is growing, the demand for current products is so high that a company can profitably raise its production volumes without high risks. In this situation, there is no point in raising the number of unrelated activities. Previous research also confirmed that the degree of corporate activity diversification is declining in growing markets (Ginevičius, 2008a).

In shrinking markets, companies find themselves in the opposite situation because the demand for current products is significantly declining. Companies can only survive by entering new, less crisis-affected markets with their new products. Thus, when markets shrink, the importance of corporate production diversification grows.

Stable markets combine the features of both growing and shrinking markets. Entering new markets is always associated with various extra costs, which means a higher risk not to achieve a desired economic result. On the other hand, an excessive narrowing of the production program may also have a negative effect because a company becomes too sensitive to demand fluctuations.

An economically reasonable number of simultaneous activities can be estimated by employing a correlation-regression analysis, the basic model of which is written as follows: $y=f(x)$. Here $y$ represents the results of commercial-economic activities (operational efficiency) in diversified companies, e.g. profit; $\mathrm{x}$ marks the number of activities. The research in the construction sector allowed to assess the impact of the scale of diversification on operational efficiency (Fig. 4) (Ginevičius, 2005).

Figure 4 indicates that the companies which have not changed the profile of their activities as well as the ones that unreasonably expanded this profile record lowest operational efficiency, which was confirmed by the results of the research in the construction sector. The general trends of the diversification process also show that the highest operational efficiency is achieved by concentrating corporate

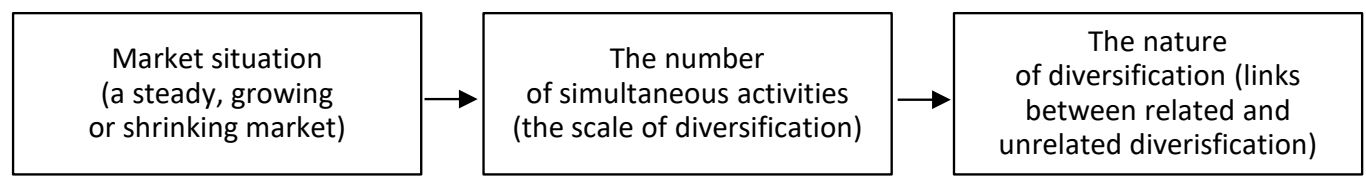

Fig. 3. Dependence of the scale and nature of corporate activity diversification on the market situation 
activities in the areas not too remote from the corporate core skill.

Previous research indicates that before the global financial crisis of 2008-2009, when the construction sector was growing steadily, companies had started narrowing their profiles because they had been making large profits from their core activities and therefore did not see any need to expand their activities to other, unrelated markets. But when the sector began to shrink, companies started expanding their profiles to have independent sources of revenue and thus offset their losses in the core market.

As can be seen in Figure 4, when the market in the EU's developing states is steady, the rational number of corporate activities in the construction sector amounts to 2-4. There is a trend that this number grows over time, which means that the quality of management in diversified construction companies is also rising. In any case, the number of simultaneous activities is significantly affected by the size of a company. These are "the two sides of a coin": when the size of a company grows, the degree of corporate activity diversification also increases, and vice versa - a rising degree of corporate activity diversification leads to the growth in the size of a company.

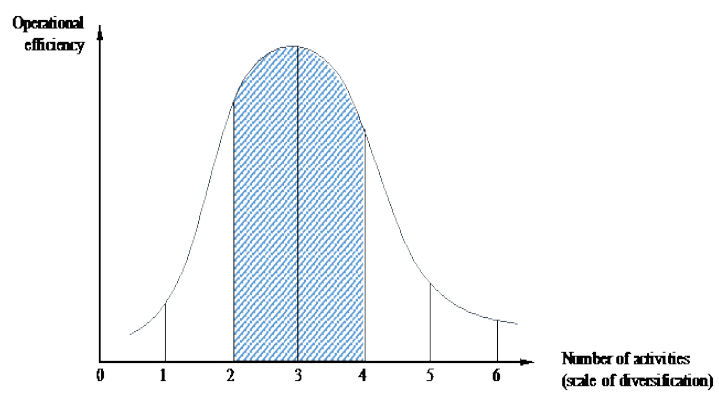

Fig. 4. Dependence of operational efficiency on the number of activities

A. Declining market

\begin{tabular}{c} 
A. Declining market \\
\begin{tabular}{|c|}
\hline Number of areas of activity \\
\hline$\longrightarrow$ increases \\
\hline Scale of diversification \\
\hline$\longrightarrow$ increases \\
\hline The nature of diversification \\
\hline related $\longrightarrow$ unrelated \\
\hline Performance of a company \\
\hline stabilizes \\
\hline Operational risk \\
\hline
\end{tabular} \\
\hline
\end{tabular}

B. A well - established market

\begin{tabular}{|c|}
\hline Number of areas of activity \\
\hline decreases $\longleftrightarrow$ increases \\
\hline Scale of diversification \\
\hline decreases $\longleftrightarrow$ increases \\
\hline The nature of diversification \\
\hline related $\longleftrightarrow$ unrelated \\
\hline Performance of a company \\
\hline getting better $\longleftrightarrow$ deteriorating \\
\hline Operational risk \\
\hline decreases $\longleftrightarrow$ increases \\
\hline
\end{tabular}

There exists a close relationship between the number of activities and the nature of diversification, i.e. between quantitative and qualitative sides of diversification: when the number of activities grows, companies move away from their core skills, which means an increase in the scale of unrelated diversification.

A generalized picture of the corporate activity diversification process depending on a market situation is presented in Figure 5.

Figure 5 indicates that a project of corporate activity diversification will be successful, if a company is able to develop an appropriate strategy and assess the whole set of conflicting conditions and, most importantly, to anticipate the changes in the market.

Organisational management conditions for the success of diversification projects should also be considered. The experience of diversified companies confirms the fact that diversification is a complex and controversial phenomenon since a large number of diversification projects fail, especially in the early stages of their implementation. The main cause of this failure is that a corporate organisational management structure does not correspond to the philosophy of diversification as the development strategy. Until the stormy development of the diversification processes between 1950 and 1970, corporate management had been dominated by an exclusively functional structure where particular management units used to specialize in the performance of well-defined functions only. Such structures were reasonable when a company focused on the release of one or several closely-related products, i.e. when a company was specialized. However, because diversification processes were developing faster than the restructuring of corporate organisational management systems, the management

Fig. 3. Dependence of the scale and nature of corporate activity diversification on the market situation

\begin{tabular}{|l|}
\hline Number of areas of activity \\
\hline decreases \\
\hline Scale of diversification \\
\hline decreases \\
\hline The nature of diversification \\
\hline Related $\longleftarrow$ unrelated \\
\hline Performance of a company \\
\hline \\
\hline getting better \\
\hline Operational risk \\
\hline
\end{tabular}

C. Growing market 
of diversified companies became inefficient, which led to low operational efficiency and even bankruptcies. It was later realized that the release of new products refers to different material-technical resources, especially in terms of technologies, i.e. it refers to new knowledge that is different from the core skill knowledge. This perception, in turn, led to the transition from a functional organisational management structure to a divisional one, i.e. formation of autonomous management units based on the released products. The main feature of this structure was the focus on different product markets.

Some scientific studies propose that the strategy of diversification seems controversial in terms of a modern organisation. It is considered that modern organisations must focus on the use of knowledge and thus develop the level of professionalism which ensures a successful competition. The development of professionalism, in turn, can only be ensured by an appropriate degree of specialization. This contradiction is fully resolved by employing a divisional organisational management structure since divisions specialize in the release of a particular product only.

The divisional organisational management structure allows a diversified company to significantly reduce its management costs by taking advantage of synergies (Hitt et al., 2001). Today, the commercial and economic performance of diversified companies, especially large ones, depends exclusively on the quality of their management.

\section{MEASURING THE LEVEL OF DIVERSIFICATION}

Measuring the level of diversification is a fundamental problem in the diversification process that is far from being fully resolved. The theory of diversification has expanded the extent of both unrelated and related diversification. This issue earns special attention in scientific studies. In order to manage the diversification process, it is necessary to quantify its level at a certain point of time. Methods for measuring unrelated diversification are most developed. They are all based either on the number of activities or estimation of the variation between the number of activities and the volumes of work. The first approach is based on the diversification index system proposed by M. Gort (Gort, 1962; Bühner, 1985; Wolf, 1995a, 1995b), while in the second case, the diversification index is estimated by the following principal expression (Wolf, 1995a, 1995b):

$$
D_{j}=\sum_{i=1}^{n} \omega_{i} P_{i}
$$

here $D j$ - diversification index; $P i$ - the relative size of activity $i ; \omega i$ - the significance of activity $i ; n$ - the number of activities.

By equating the significance of a particular activity to its relative size $(\omega i=P i)$, the Herfindahl concentration index is obtained:

$$
D_{H}=\sum_{i=1}^{n} P_{i} P_{i}=\sum_{i=1}^{n} P_{i}^{2}
$$

Since production concentration is the opposite of production diversification, the Herfindahl index is transformed to obtain Berry diversification index (Berry, 1971):

$$
D_{B}=1-D_{H}=1-\sum_{i=1}^{n} P_{i}^{2}
$$

For measuring unrelated diversification, the entropy and Uton indices are also used (Jackuemin et al., 1979; Palepu, 1985; Uton, 1977).

$$
\begin{gathered}
E_{D}=\sum_{i=1}^{n} P_{i} \ln \frac{1}{P_{i}} \\
W_{u}=2 \sum_{i=1}^{n} i P_{i}-1
\end{gathered}
$$

here: $E d$ - diversification entropy index; $W u$ - Uton diversification index.

The main shortcoming of the abovediscussed methods applied for measuring diversification is insufficient methodological substantiation. Gort indices are imperfect because they are linked to limited classification systems, i.e. they do not cover all areas of corporate activities and do not estimate the variation among them.

The value of the most common Berry index is directly affected by the variation in the volumes of work, thus this index does not consider the number of activities, though namely the latter determines the changes in the organisational management structure in a diversified company.

For improvement of the Berry index, the following diversification measure is proposed (Ginevičius, 2009):

$$
D_{G}=1-\frac{1}{\sum_{i=1}^{n} \frac{1-P_{\max }}{1-P_{i}}}
$$

here: $D G$ - unrelated diversification index; Pmax the relative size of the largest activity by volume.

In order to illustrate the situations in Figure 5 with a real example, a typical period of 2005-2019, 
which incorporates all three market stages (periods 2005-2007, 2008-2009 and 2010-2019, respectively), will be considered.

Period 2005-2007 represents a growing market characterised by the tendency that Lithuanian construction companies, which generate a substantial share of the country's GDP, were granted major restriction-free bank loans on exceptionally good terms, which led to a disproportional expansion of the construction sector and a "price bubble" formation. Construction companies did not need to expand their business profiles as they earned steady revenues from their core activities, which is evidenced by the low values of diversification indicators (see Table 1).

The small effect of diversification on corporate commercial performance is also confirmed by the results of the correlation-regression analysis (see Table 2).

As can be seen in Table 2, over the period 20052007, the effect of diversification on corporate commercial profitability was weak.

Period 2008-2009 represents the global financial crisis characterised by the burst of the "price bubble", i.e. the construction sector shrank significantly, corporate revenues fell, and corporations had no reserves to repay bank loans. The situation resulted in the bankruptcies of a significant number of construction, retail and wholesale companies which possessed no independent sources of revenue, i.e. they had failed to expand their business profile on time. On the other hand, the other part of business companies were aware of the impending danger and prepared for it accordingly: they diversified their activities to introduce new products to the markets less affected by the crisis, which is evidenced by the higher values of diversification indicators (see Table 1) as well as the results of the correlation-regression analysis disclosing the links between corporate commercial performance and the degree of diversification (see Table 2).

The third period (2010-2019) is characterised by a well-established market. In this situation, companies achieve their best commercial results when they, on one hand, do not unreasonably narrow their business profiles, on the other hand, do not develop new products unreasonably remote from the core product, and can therefore exploit the same technologies and knowledge without any need to change their organisational management structures, etc. This is evidenced by the values of the diversification indicator as well as the results of the correlation-regression analysis (see Tables 1 and 2).
Tab. 1. Average values of diversification indicators of the companies operating in the Lithuanian construction sector

\begin{tabular}{|c|r|r|r|}
\hline \multirow{2}{*}{$\begin{array}{c}\text { VAlUES OF } \\
\text { DIVESIFICATION } \\
\text { INDICATORS }\end{array}$} & 2005-2007 & 2008-2009 & 2010-2019 \\
\cline { 2 - 4 } & 0.23 & - & 0.3 \\
\hline$D_{B}$ & 0.27 & 0.4 & 0.3 \\
\hline$D_{G}$ & & & 0.3 \\
\hline
\end{tabular}

Tab. 2. Dependence of commercial profitability of the companies operating in the Lithuanian construction sector on the degree of diversification

\begin{tabular}{|c|c|c|}
\hline $\begin{array}{c}\text { Period, } \\
\text { Years }\end{array}$ & Regression Equation & $\begin{array}{c}\text { VAlUe } \\
\text { Of CORRELAtion } \\
\text { COEfFICIENT } \boldsymbol{R}\end{array}$ \\
\hline $2005-2007$ & $E=0.14+10.450 D_{G}+9.888 D_{G}{ }^{2}$ & 0.22 \\
\hline $2008-2009$ & $E=0.134+0.026 D_{G}$ & 0.66 \\
\hline $2010-2019$ & $E=0.195+0.025 D_{G}$ & 0.42 \\
\hline
\end{tabular}

Estimation of the scale of unrelated diversification is based on the presumption that corporate activities are not related either technologically or in any other way. But the reality is usually different, so the actual picture of diversification is distorted. Thus, to further improve the quantitative estimation of the scale of diversification, new methods need to be developed.

The methods applied for qualitative estimation of the scale of related diversification are even less developed, though this aspect of diversification is extremely important considering the fact that different corporate activities are technologically or in any other way related to the core activity. Probably due to the difficulty to quantitatively estimate these relations, the scale of related diversification is commonly measured by employing the discretecategorical measure (Wrigley, 1970). The essence of this method is that all companies are divided into four categories: single product, dominant product, related product and unrelated product. Practical application of this concept revealed a number of shortcomings, which led to its subsequent refinement by Rumelt (Rumelt, 1974). Nevertheless, even this methodology does not provide a reliable basis for measuring related diversification. The latest methods for measuring this type of diversification include Varadarajan and Ramanajan's (Varadarajan \& Ramanujan, 1987) suggestions which, however, are highly subjective.

The main drawback of the above-discussed methods developed for measuring the scale of related 
diversification is that they do not consider quantitative estimation, which is considered in the following index (Ginevičius, 2012):

$$
D_{s}=1-\frac{\sum_{i=1}^{n} \frac{W_{i}}{P_{\max }} P_{i}}{1-P_{\max }}
$$

here: $D s$ - index of the related corporate activity diversification; $W i$ - aggregate strength of the relationship between the ith product-market combination and the core product-market combination; Wmax - the largest possible value of the relationship between the ith product-market combination and the core product-market combination.

Formula (7) indicates that the related diversification measurement is based on the quantitatively expressed strength of the relationship between all product-market combinations and the core product-market combination.

Average values of the indicator of related diversification estimated for construction companies in different periods of the term under consideration are presented in Table 3.

The low value of unrelated diversification (see Table 1) and the high value of related diversification (see Table 3) indicate that when the number of simultaneous activities is decreasing, companies are moving closer to their core products, i.e. they exploit the same production technologies. All this is typical of a growing market.

When the degree of unrelated diversification increases, the degree of related diversification decreases (see Tables 1 and 3), which means that when the number of simultaneous activities declines, companies move away from their core production technologies and start applying new ones that differ from the former. At the same time, the opportunities to sell new products in new markets appear.

In a well-established market, the degree of unrelated diversification decreases, which prompts

Tab. 3. Average values of the indicator of related diversification for construction companies under consideration

\begin{tabular}{|l|c|c|c|}
\hline $\begin{array}{c}\text { PERIODS OF } \\
\text { THE TERM } \\
\text { UNDER CON- } \\
\text { SIDERATION, } \\
\text { YEARS }\end{array}$ & 2005-2007 & 2008-2009 & 2010-2019 \\
\hline $\begin{array}{l}\text { Value of } D_{s} \\
\text { indicator }\end{array}$ & 0.47 & 0.15 & 0.35 \\
\hline
\end{tabular}

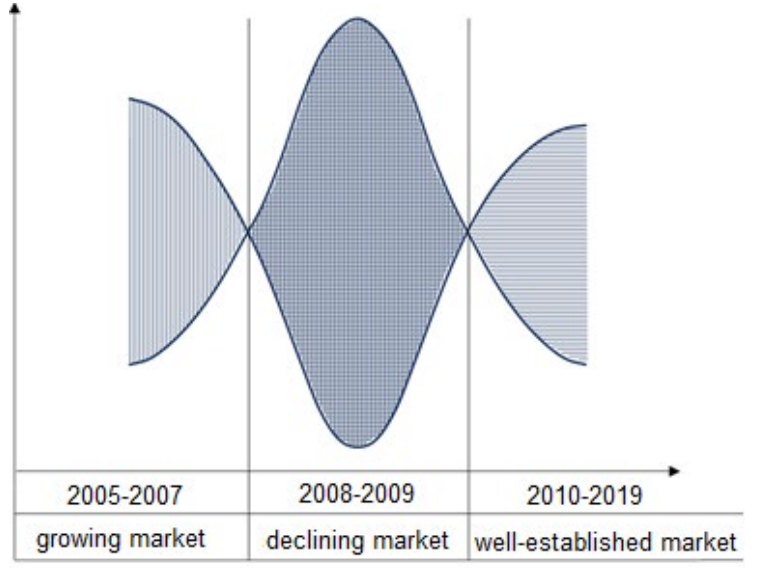

Fig. 6. Tendencies of corporate activity diversification depending on the market situation observed in the construction sector

companies to move closer to their core products, thus the degree of related diversification increases accordingly (see Tables 1 and 3).

Summarising, the following generalized picture of the interrelations between unrelated and related diversification depending on the market situation emerges (see Fig. 6).

Nevertheless, this method for measuring the scale of corporate activity diversification does not resolve the problem of how the measure of related diversification can be integrated into the measure of unrelated diversification, which is important because only by integrating these two measures, a complex estimation of the scale of diversification can be conducted. The above-discussed issues of corporate activity diversification require further research.

\section{CONCLUSIONS}

Corporate activity diversification is a process of high complexity and its assessment is controversial. On one hand, diversification creates opportunities to disperse the market activity and thus ensure longterm financial stability; on the other hand, as a development strategy, it is relatively risky.

The basic issues of the diversification process that have not yet been fully resolved are as follows: preconditions and conditions for making a decision on corporate activity diversification; the problem of the scale and nature of diversification; organisational management conditions for the success of diversification projects; measuring the achieved level of diversification;

Resolution of the first issue requires the improvement of the methodology for analysing the internal and external business situation. An 
organisation that is not properly prepared for activity diversification is bound for failure.

The scale and nature of diversification depend on the market situation, i.e. it depends on whether a market is growing, shrinking or steady. In shrinking markets, the number of activities rises along with the scale of unrelated diversification, which allows stabilising corporate financial performance, but raises operational risks.

In growing markets, by contrast, the number of activities decreases along with the scale of diversification (the related diversification is predominant), operational efficiency improves, and risks decline.

Effective management of a diversified company is ensured by the transition from a functional to a divisional organisational management structure, though the issues of the effective management of large diversified companies remain unsolved.

Successful management of the diversification process calls for the adequate estimation of the scale of diversification at a particular point of time. The most common measures of unrelated diversification are based on the presumption that corporate activities are not related either technologically or in any other way. However, because the reality is usually different, these measures provide a distorted picture of diversification. Thus, to further improve the adequacy of quantitative estimation of the scale of diversification, new methods need to be developed.

Related diversification is commonly estimated by applying the discrete-categorical, i.e. qualitative measure. Nevertheless, without a quantitative estimation, integration of the measures of unrelated and related diversification into a single generalizing index is impossible, as is a complex estimation of the scale of diversification.

\section{LITERATURE}

Amik, R., Livnat, J., \& Zarowin, P. (1989). The Mode of Corporate Diversification: Internal Ventures versus Acquisitions. Managerial and Decision Economics, 10(2), 89-100.

Anghel, I., Enache, C., \& Merino, F. (2020). Macroeconomic determinants of corporate failures. Evidence from Romania and Spain. Journal of Business Economics and Management, 21(3), 743-759. doi: 10.3846/ jbem.2020.12217

Ansoff, H. J. (1957). Strategies for Diversification. Harvard Business Review, 35(5), 111-125.

Ansoff, H. J. (1965). Corporate Strategy. New York: McGraw-Hill Book Comp.
Arbeitskreis. (1973). Diversifizierung, Zeitschrift für betriebswirtschaftliche. Forschung, 25, 294-335.

Becerra, M., \& Santaló, J. (2006). The Effect of Diversification on Performance Revisited: How the Dominance of Diversifiers Versus Specialists Drives the Diversification-Performance Relationship. Management Research, 4(1), 23-34. doi: 10.2753/JMR15365433040102

Berry, Ch. (1971). Corporate Growth and Industrial Diversification. Journal of Law and Economics, 14, 371383.

Bilan, Y., Vasilyeva, T., Lyeonov, S., \& Bagmet, K. (2019). Institutional complementarity for social and economic development. Business: Theory and Practice, 20, 103-115. doi: 10.3846/btp.2019.10

Bühner, R. (1985). Strategie und Organisation. Wiesbaden, Germany: Gabler.

Busse, M., Dacorogna, M., \& Kratz, M. (2014). The Impact of Systemic Risk on the Diversification Benefits of a Risk Portfolio. Risks, 2(3), 260-276. doi: 10.3390/ risks2030260.

Chen, Y., Jiang, Y., Wang, C., \& Chung Hsu, W. (2014). How do resources and diversification strategy explain the performance consequences of internationalization? Management Decision, 52(5), 897-915. doi: 10.1108/MD-10-2013-0527.

Chen, Y.-Y., \& Jaw, Y. L. (2014). How do business groups' small world networks effect diversification, innovation, and internationalization? Asia Pacific Journal of Management, 31(4), 1019-1044. doi: 10.1007/ s10490-014-9385-9

Chonghui, J., Yongkai, M., \& Yunbi, A. (2013). International diversification benefits: an investigation from the perspective of Chinese investors. China Finance Review International, 3(3), 225-249.

Chung, H.-M. (2013). The role of family management and family ownership in diversification: The case of family business groups. Asia Pacific Journal of Management, 30(3), 871-891. doi: 10.1007/s10490012-9284-x

Dickinson, V. (2005). Firm Life Cycle and Future Profitability and Growth. Working paper. Madison, USA: School of Business, University of Wisconsin.

Ejdys, J., Gudanowska, A., Halicka, K., Kononiuk, A., Magruk, A., Nazarko, J., Nazarko, Ł., Szpilko, D., \& Widelska, U. (2019). Foresight in Higher Education Institutions: Evidence from Poland. Foresight and STI Governance, 13, 77-89. doi: 10.17323/25002597.2019.1.77.89

Gaur, A., \& Delios, A. (2015). International Diversification of Emerging Market Firms: The Role of Ownership Structure and Group Affiliation. Management International Review, 55, 235-253. doi: 10.1007/s11575015-0240-0

Ginevičius, R. (1998a). Imonés situacija ir strategija [Corporate situation and strategy]. Vilnius, Lithuania: Technika.

Ginevičius, R. (1998b). Imonès veiklos diversifikacija [Diversification Activities of Enterprises]. Vilnius, Lithuania: Technika.

Ginevičius, R. (2009). Quantitative evaluation of unrelated diversification of enterprise activities. Journal of 
Civil Engineering and Management, 15(1), 105-111. doi: 10.3846/1392-3730.2009.15.105-111.

Ginevičius, R. (2012). İmonių susijusios diversifikacijos matavimas. Verslas: teorija ir praktika $=$ Business: Theory and Practice, 13(2), 150-159.

Ginevičius, R., \& Andruškevičius, A. (2008a). Construction Enterprises on the Efficiency of their Commercial and Economic Activities. The 5th International Scientific Conference "Business and Management", 16-17 May, Vilnius, Lithuania.

Ginevičius, R., \& Andruškevičius, A. (2008b). The Influence of Diversification of Construction Enterprises on the Efficiency of their Commercial and Economic Activities. The 5th International Scientific Conference "Business and Management 2008", 16-17 May, Vilnius, Lithuania.

Ginevičius, R., \& Podvezko, V. (2008). Determining the optimal number of enterprise activities. The 5th International Scientific Conference "Business and Management 2008”, 16-17 May, Vilnius, Lithuania.

Ginevičius, R., \& Podvezko, V. 2005. Generation of a set of evaluation criteria. Business: Theory and Practice, 6(4), 199-207.

Gort, M. (1962). Diversification and Integration in American Industry. Princeton.

Gort, M., \& Klepper, S. (1982). Time Paths in the Diffusion of Product Innovations. Economic Journal Royal Economic Society, 92(367).

Hann, R., Ogneva, M., \& Ozbas, O. (2013). Corporate Diversification and the Cost of Capital. Journal of Finance, 68(5), 1961-1999. doi: 10.1111/jofi.12067

Hernández-Trasobares, A., \& Galve-Górriz, C. (2016). The influence of family control on decisions regarding the specialization and diversification of business groups. BRQ Business Research Quarterly, 19(2), 73-89. doi: 10.1016/j.brq.2015.09.001

Hitt, M., Ireland, R., \& Hoskisson, R. (2001). Strategic Management: Competitiveness and Globalisation. 4th ed. Cincinnati, USA: South-Western College Publishing.

Hyland, D. C. (2003). The Effect of Diversification on Firm Value: a Pre- and Post- Diversification Analysis. Studies in Economics and Finance, 21(2), 22-39. doi: 10.1108/eb028773

Jackuemin, A. P., \& Berry, C. H. (1979). Entropy Measure of Diversification and Corporate Growth. Journal of Industrial Economics, 27, 46-57.

Jara-Bertin, M., López-Iturriaga, F. J., \& Espinosa, Ch. (2015). Diversification and control in emerging markets: The case of Chilean firms. BRQ Business Research Quarterly, 18(4), 259-274. doi: 10.1016/j. brq.2015.01.002

Kieser, A., \& Kubicek, H. (1992). Organization. 3. Völling neu Bearb. Aufl. Berlin, New York: de Gruyter.

Kim, S. W., Kim, T., Choi, K.-H., \& Yang, J. A. (2014). Comparative Analysis of the Diversification Effects between Firm Performance and Whole Supply Chain Performance in Korea and Japan. Journal of Korea Trade, 18(1), 1-27.

Knapková, M., Kiaba, M., \& Hudec, S. (2019). Impact of macroeconomic indicators on public debt of Slovak Republic. Journal of Business Economics and Management, 20(4), 734-753. doi: 10.3846/ jbem.2019.10184

Kuppuswamy, V., Serafeim, G., \& Villalonga, B. (2014). The Effect of Institutional Factors on the Value of Corporate Diversification. Finance and Strategy, 31, 37-68. doi: 10.1108/S0742-332220140000031000

Lehmann, R. (1993). Kann Diversifikation Wert schaffen? Bern, Stuttgart, Wien: Haupt.

Li, D., Li, L., \& Huang, Y. (2013). Technological Diversification Effect on Business Performance: A Probing into Intermediaries Role of Product Innovation Strategy. 8th International Conference on Intelligent Systems and Knowledge Engineering and Management 278, 181-190. doi: 10.1007/978-3-642-54930-4 18

Mackey, T. B., \& Barney, J. B. (2013). Incorporating opportunity costs in strategic management research: The value of diversification and payout as opportunities forgone when reinvesting in the firm. Strategic Organization, 11(4), 347-363. doi: $10.1177 / 1476127013481447$

Macsimovic, V., \& Gordon, Ph. (2005). The Industry Life Cycle and Acquisitions and Investment: Does Firm Organisation Matter? Cambridge, USA: University of Maryland, CES.

Mauer, D. C., Wang, S., Wang, X., \& Zhang, Y. (2015). Global diversification and IPO returns. Journal of Banking \& Finance, 58, 436-456. doi: 10.1016/j. jbankfin.2015.05.015

Miller, D. J. (2006). Technological diversity, related diversification, and firm performance. Strategic Management Journal, 27(7), 601-619. doi: 10.1002/smj.533

Montgomery, C. A. (1994). Corporate Diversification. The Journal of Economic Perspectives, 8, 163-168.

Nazarko, J., Ejdys, J., Halicka, K., \& Nazarko, Ł. (2015). Foresight Application for Transport Sector. In M. Fiorini (Ed.), Clean Mobility and Intelligent Transport Systems (pp. 379-402). London: The Institution of Engineering and Technology. doi: 10.1049/PBTR001E ch17

Nazarko, J., Ejdys, J., Halicka, K., Nazarko, Ł., Kononiuk, A., \& Olszewska, A. (2007a). Factor Analysis as a Tool Supporting STEEPVL Approach to the Identification of Driving Forces of Technological Innovation. Procedia Engineering, 182, 491-496. doi: 10.1016/j.proeng.2017.03.142

Nazarko, J., Ejdys, J., Halicka, K., Nazarko, Ł., Kononiuk, A., \& Olszewska, A. (2007b). Structural Analysis as an Instrument for Identification of Critical Drivers of Technology Development. Procedia Engineering, 182, 504-509. doi: 10.1016/j.proeng.2017.03.137

Nazarova, V. (2015). Corporate Diversification Effect on Firm Value (Unilever Group Case Study). Annals of Economics and Finance, 16(1), 173-198.

Palepu, K. (1985). Diversification Strategy, Profit Performance and the Entropy measure. Strategic Management Journal, 6, 238-245.

Pennings, J. M., Barkema, H., \& Douma, S. (1994). Organizational learning and diversification. Academy of Management Journal, 37(3), 608-640. doi: $10.2307 / 256702$

Pierscionek, Z. (1966). Strategie rozwoju firmy [Company development strategies]. Warszawa, Poland: Wydawnictwo Naukowe PWN. 
Qian, G., Li, L., \& Rugman, A. M. (2013). Liability of country foreignness and liability of regional foreignness: Their effects on geographic diversification and firm performance. Journal of International Business Studies, 44(6), 635-647. doi: 10.1057/jibs.2013.21

Rumelt, R. (1974). Strategy, Structure and Economic Performance. Boston: Harvard University Press.

Sanchez-Bueno, M., \& Usero, B. (2014). How may the nature of family firms explain the decisions concerning international diversification? Journal of Business Research, 67(7), 1311-1320. doi: 10.1016 /j.jbusres.2013.09.003.

Santarelli, E., \& Tran, H. T. (2016.) Diversification strategies and firm performance in Vietnam Evidence from parametric and semi-parametric approaches. Economics of Transition and Institutional Change, 24(1), 31-68. doi: 10.1111/ecot.12082

Sawada, M. (2013). How does the stock market value bank diversification? Empirical evidence from Japanese banks. Pacific-Basin Finance Journal, 25, 40-61. doi: 10.1016/j.pacfin.2013.08.001

Schmid, T., Ampenberger, M., Kaserer, Ch., \& Achleitner, A.-K. (2015). Family Firm Heterogeneity and Corporate Policy: Evidence from Diversification Decisions. Corporate Governance: An International Review, 23(3), 285-302. doi: 10.1111/corg.12091.

Schüle, F. M. (1992). Diversifikation und Unternehmenserfolg: eine Analyse empirischer Forschungsergebnisse. Wiesbaden, Germany: Gabler.

Teece, D. J., Rumelt, R., Dosi, G., \& Winter, S. (1993). Understanding corporate coherence: Theory and evidence. Journal of Economic Behavior \& Organization, 23(1), 1-30. doi: 10.1016/0167-2681(94)900949

Thoumrungroje, A., \& Tansuhaj, P. (2005). Entrepreneurial Strategic Posture, International Diversification, and Firm Performance. Multinational Business Review, 3(1), 55-73.

Uton, M. A. (1977). Large Firm Diversification in British Manufacturing Industry. Economic Journal, 87, 6-11.

Varadarajan, P., \& Ramanujan, V. (1987). Diversification and Performance. A Reexamination Using a New Two-Dimensional Conceptualization of Diversity in Firms. Academy of Management Journal, 30, 380393.

Wan, W. P., \& Hoskisson, R. E. (2003). Home country environments, corporate diversification strategies, and firm performance. Academy of Management Journal, 46(1), 27-45. doi: 10.2307/30040674

Wang, Y., Ning, L., \& Chen, J. (2014). Product diversification through licensing: Empirical evidence from Chinese firms. European Management Journal, 32(4), 577-586. doi: 10.1016/j.emj.2013.09.001

Wolf, J. (1995a). Die Messung des Divertifikationsgrads von Unternehmen (I). Wirtschaftsstudium, 5, 439445.

Wolf, J. (1995b). Die Messung des Divertifikationsgrads von Unternehmen (II). Wirtschaftsstudium, 6, 519523.

Wrigley, L. (1970). Divisional Autonomy and Diversification. Boston: Harvard Business School.
Yahaya, M. I., Aliyu, M. I., \& Kabir, B. (2009). Geographic diversification, performance, and the risk profile of UK construction firms. Journal of Engineering, Design and Technology, 7(2),171-185.

Yücel, E., \& Önal, Y. B. (2015). Industrial Diversification and Risk in an Emerging Market: Evidence from Turkey. Emerging Markets Finance and Trade, 51(6), 1292-1306. doi: 10.1080/1540496X.2015.1011544

Zahavi, T., \& Lavie, D. (2013). Intra-industry diversification and firm performance. Strategic Management Journal, 34(8), 978-998. doi: 10.1002/smj.2057

Zhipeng, Y. (2006). New Methodology of Measuring Corporate Life-Cycle Stages. Waltham, USA: Brandeis University International Business School. 